\title{
Use Patents, Carve-Outs, and Incentives - A New Battle in the Drug-Patent Wars
}

Arti Rai, J.D.

The Drug Price Competition and Patent Term Restoration Act of 1984, commonly known as the Hatch-Waxman Act, aims to strike a balance between the innovation incentives provided by patents and the greater access provided by low-cost generic drugs. The legislation, which relies in part on an explicit link between the Food and Drug Administration (FDA) drug-approval process and the U.S. patent system, has been controversial, particularly because of the ways in which firms producing brandname drugs have exploited that link to delay market entry of generics as long as possible. Now, the tactical landscape has shifted again, with a recently decided Supreme Court case, Caraco Pharmaceutical Laboratories v. Novo Nordisk.

Under current FDA regulations, the developer of a brandname drug must submit all patents that it deems to cover the drug to the FDA for publication in the agency's Approved Drug Products with Therapeutic Equivalence Evaluations - the so-called Orange Book. Before marketing a generic version of a drug, the generics manufacturer must certify that all Orange Book patents for the brand-name product are invalid, are not infringed by the generic product, or have expired. Certifications that patents that are invalid or not infringed, known as Paragraph IV certifications, allow the brand-name drug maker to sue the generics manufacturer to resolve questions of validity and infringement. As a result, FDA approval of the generic drug can be delayed for up to 30 months pending legal resolution.

Orange Book listings can include both product patents on small-molecule chemicals and patents on methods of use for treating particular conditions. FDA regulations require that, in addition to patent numbers and expiration dates, method-of-use patents must have "use codes" that describe their scope.

Frequently, the main product patent on a brand-name drug expires before the use patents do. In that case, FDA regulations based on Hatch-Waxman allow generics firms the option of filing a "section viii statement," which "carves out" from the generic label those uses on which the brand-name firm still has patents. If the FDA finds this narrower labeling acceptable from the standpoint of safety and efficacy, the generic version has a potential path to market.

Brand-name drug manufacturers have sometimes tried to sue to prevent market entry by generics companies that file section viii statements, typically arguing that although a generics firm may not be directly infringing a use patent, it should be prohibited from marketing its product because such marketing will inevitably "induce" infringement. In other words, the generic-substitution practices of doctors and pharmacists - encouraged by FDA approval of "carved-out" generics as fully substitutable for brand-name drugs and by laws in many states - will inevitably lead to prescription of generic drugs for patented uses. Moreover, brand-name pharmaceutical firms argue that generics firms should be held liable because they are well aware that their products will be prescribed and dispensed in an infringing manner.

The Court of Appeals for the Federal Circuit, the intermediate appellate court for patent cases, has held that as a procedural matter, courts may hear suits brought by brand-name firms in response to a section viii statement filing. However, it has generally rejected the substantive claim of induced infringement, holding that because inducement requires more than mere knowledge that infringement is occurring, the generics firm cannot be held liable unless it specifically promoted the drug for a carvedout use. ${ }^{1}$

In recent years, carve-out labeling has assumed a prominent role in facilitating market entry of generics. For example, in fiscal year 2010, the FDA approved 11 generic drugs with carve-out labeling. In fact, 3 of the 5 topselling brand-name drugs that "went generic" that year did so as a consequence of such labeling. ${ }^{2}$

On occasion, brand-name drug manufacturers have attempted to defeat carve-out attempts by listing use codes that substantially exceed the scope of the use patent. This tactic can be effective, since the FDA does not evaluate 
representations of patent information in use codes. ${ }^{3}$

In April 2012, however, the Supreme Court issued a decision enabling generics firms to challenge the submission to the FDA of overly broad use claims. In Caraco, Novo Nordisk's only unexpired patent covered a relatively narrow use - treating non-insulin-dependent diabetes by combining its diabetes drug repaglinide with another drug, metformin. In the Orange Book, however, Novo Nordisk listed a much broader use code that covered all methods for "improving glycemic control in adults with type 2 diabetes mellitus," thereby denying generics firms a meaningful carve-out. cision is correct. Both the language and legislative history of the 2003 amendments indicate that Congress intended to control inaccurate Orange Book listing practices with respect to product patents and method-ofuse patents. Such misleading practices had been thoroughly documented in a 2002 Federal Trade Commission report. However, as Justice Sonia Sotomayor's concurrence points out, the mechanism provided by Congress is far from optimal. A claim to correct overbreadth can be filed only if the generics firm chooses to provoke litigation by filing a Paragraph IV certification and the brand-name firm then sues for

\section{If the main product patent on a brand-name} drug expires before the use patents do, generics firms can apply to the FDA to "carve out" patented uses from the generic label and potentially gain a path to market.

The key question in this case was whether amendments to Hatch-Waxman implemented in 2003 allowed generics firms, in the course of a patent-infringement lawsuit brought by the brandname company, to file a counterclaim to correct overly broad listings of Orange Book use codes. The unanimous opinion of the Court, delivered by Justice Elena Kagan, held that the amendments were indeed intended to correct such overbreadth. As Kagan noted, absent the ability to correct overbreadth, a company could not market a generic drug for noninfringing uses.

As a matter of statutory interpretation, the Supreme Court de- infringement. An administrative approach to determining the accuracy of Orange Book listings - an approach in which the FDA might, for example, consult with the Patent and Trademark Office - would clearly be more efficient. Lurking behind these technical legal disputes over carve-outs, induced infringement, and overly broad Orange Book listings is the broader policy issue of providing incentives to search for new uses. Brand-name pharmaceutical companies argue that the pervasive distribution of generic drugs for patented uses substantially undermines the efficacy of such patents and hence the incentives for finding other uses. ${ }^{4}$
Strong incentives are probably unnecessary for purposes of generating hypotheses regarding new uses. The heavy prevalence of off-label prescribing - which accounted for more than $20 \%$ of prescriptions written by officebased physicians in 2001, according to one study 5 - suggests that hypotheses are pervasive. The incentives question is important, however, because the ultimate objective, from the standpoint of both patient welfare and cost, is reliable evidence of efficacy. Such evidence, which is required before the FDA can approve labeling (or allow marketing) for a new use, is generated through investment in well-designed trials.

Such investment need not emerge, however, only from individual firms operating in secrecy and motivated by patents. Indeed, one recent study found that publicly funded research formed the foundation for almost all the newuse FDA approvals that were examined. ${ }^{6}$ Going forward, the public sector's role is likely to increase - the new National Center for Advancing Translational Sciences at the National Institutes of Health has explicitly embraced the search for new uses in a number of the programs it is funding.

In many arenas of innovation, proprietary research models supported by intellectual property and publicly funded open research models not only coexist, they play mutually reinforcing, synergistic roles. Brand-name firms could view Caraco's partial restriction on their deployment of overly broad use claims as an opportunity to rely less on dubious legal tactics and more on the pursuit of opportunities to leverage public-sector investment. 
Disclosure forms provided by the author are available with the full text of this article at NEJM.org.

From the Duke University School of Law, Durham, NC.

1. Warner-Lambert Co. v. Apotex, 315 F.3d 1348 (Fed. Cir. 2003).
2. Brief for the United States as amicus curiae supporting petitioners, Caraco v. NovoNordisk, 2011.

3. 68 Fed. Reg. 36683 (2003).

4. Eisenberg RS. The problem of new uses. Yale J Health Policy Law Ethics 2005;5:71739.

5. Radley DC, Finkelstein SN, Stafford RS. Off-label prescribing among office-based physicians. Arch Intern Med 2006;166: 1021-6.

6. Stevens AJ, Jensen JJ, Wyller K, Kilgore PC, Chatterjee S, Rohrbaugh ML. The role of public-sector research in the discovery of drugs and vaccines. N EnglJ Med 2011;364:535-41.

DOI: 10.1056/NEJMp1206573

Coppright (๑) 2012 Massachusetts Medical Society. 